\title{
Festivals: Catalyst for Peace in Nigeria
}

\author{
Grace Lawrence-Hart, Ph.D \\ Department of Religious and Cultural Studies Ignatius Ajuru University of Education Rumuolemini, Port \\ Harcourt, Rivers State
}

\begin{abstract}
Nigeria is going through a myriad of conflict ranging from sectarian, youth restiveness; ethnic variance etc. these conflicts most often are violent and destructive of human and public structures, thus, a unifying activity in the form of festivals is needed. Festivals are special occasion which are generally marked by merry-making. Its observance brings about social and moral control as well as entertainment. It attracts visitors to a place and also affects the economy, conserve culture and rejuvenate traditions. Festivals provide a potent platform to guarantee peace if properly organized and can contribute in creating an enabling peaceful atmosphere for all to dwell in. This is because peace which is the absence of violence is key to development. Festivals whether religious or secular brings people together irrespective of their social standing as it provides an avenue for outlet to all and sundry while building social cohesion and reinforce ties within people. Although there have been advocacy by government and different interest group on approaches to achieve peace, festivals have not been identified as a bridge for peaceful co-existence. As a result, this work sets out to x-ray the ethnological and phenomenological review of selected festivals in Nigeria and its gain in fostering unity and peaceful co-existence among the people, with the aid of available documents on Nigerian festivals. Our submission therefore, is that if festive activities are organized regularly, it will go a long way in creating a platform for peaceful co-existence in the nation. Reason being that Nigeria as a nation is multi-cultural with divers tribes and tongues and multi-religious, hence, needs a platform for effective and meaningful intercultural communication and understanding.
\end{abstract}

\section{Introduction}

Festivals are occasions for feasting or celebration, especially a day or time of religious significance that recurs at regular intervals or an often regularly recurring program of cultural performance, exhibition or competitions (The America Heritage Dictionary 2009). Festivals whether religious, cultural or secular play a very essential role in any local community, because it helps to develop the pride and identity of a people. Festivals provide an opportunity for the local communities to develop and share their culture, it showcases values and beliefs held by the individuals in a local community and provide opportunity for members of the local community to exchange experiences and information. Festivals provide visitors the opportunity to see how the local communities celebrate their culture thereby creating room for intercultural communication and help people to enjoy and meet their leisure needs. Peace which is the absence of violence is key to the development of any country especially Nigeria that is multi-cultural, multi-religious with divers tribes and tongues. Enduring peace is crucial for the development of any region; in addition, it ensures harmony among people of different cultural and religious group. Therefore, it is imperative to promote activities that will bring people together with a unifying purpose. This is because an atmosphere of peace stimulates enabling environment which will attract investors and in turn boost the economy of the locality. Moreso, peace and unity is very essential for national development, hence, should not be undermined. To this end, harnessing different strategies which will bring about restoration of durable peace in the nation is very vital for the prosperity and progress of the country. Festivals therefore, is one measure which if considered will bring people together because festivals irrespective of its nature, promote cultural exchange thereby increasing understanding among people of different regions.

\section{Taxonomy of Festivals}

Festivals could be religious, cultural or secular in nature, man generally is full of celebration to mark one event or achievement hence the need for celebration either for commemoration or for appreciating the Supreme Being. Most of these festivals especially cultural festivals are influenced by the environment and they are grouped according to their functions to the different communities. According to Pilgrim R. (1978:65) as recorded by Ejizu (2007:84) festivals are categorized thus: festivals associated with ecological cycles that regulate seasonal changes which determines planting, harvesting and natural order, festivals associated with non-ecological liturgical calendars that follow regular cyclic pattern, that is, celebration of human cycle that mark stages of human life cycle like rites of passages, birth, initiation, marriage etc. and occasional festivals, 
these do not follow regular cycle but is staged on demand when necessary. Within this category of festivals is religious, agricultural and cultural which sometimes can be also hosted occasionally.

Below are the different types of festivals:

\section{Religious Festivals}

Religious festivals are celebrated to honour the Supreme Being and the different deities in the communities or to mark a special event in a particular religion; it is headed either by a religious priest, the head of the family or the king where necessary, this kind of festivals falls under the festivals of non-ecological liturgical calendars. For instance, Christmas, Easter, Id-el-fitri, Id-el-Malud, for Christians and Muslim respectively, Owh'Oyede festivals of the Isoko people, Edjo festivals among the Urhobo people in honour of Omaloku, Osun Osogbo festivals in honour of the Osun River goddess etc.

\section{Agricultural Festivals}

Agricultural festivals are festivals associated with ecological cycle; it symbolizes the conclusion of a work cycle and the beginning of another. For instance the new yam festivals celebrated within August and November in the various towns and villages in Nigeria, the opening of the creeks among the riverine people of Rivers State, where the creek is traditionally locked up in other to allow the periwinkles, oyster, fish, etc. to mature very well (For instance, Okolofingiari among the people of Bonny) before they are harvested. Agricultural festivals are celebrated to appreciate the earth goddess, the deities and the ancestors for a fruitful harvest. The new yam festivals like other agricultural festivals are celebrated in this form; first invitation is usually open to everyone. What this means is that there is abundant food for not just the harvesters but also for friends and well-wishers. A variety of festivities mark the eating of the new yam. These festivities include cultural dances, masquerades parades, parties, etc. all these activities brings people together and create a platform for peaceful co-existence.

\section{Occasional Festivals}

These are occasion to mark the achievement of one special feat or another Ejizu (2007:86). Occasional festivals can also be regarded as secular festivals. In the pre-modern times festivals were held either to remember conquest in battles, eradication of an epidemic that has ravaged a community or the killing of a terrible animal that once threatened the community etc. This type of occasional events occurred for memorial purpose. As these occasions are held, the elders use the opportunity to tell the younger generation of what happened in the past. This also aided the transmission of the stories of cultural heritage from generation to generation.

However, in these modern times such occasional festivals are held to herald the return of a man/woman who has made it in his chosen career or contributed meaningfully in the development of his community. This type of celebration encouraged hard work among the people as they see it as a mark of honour. Different dance group and masquerades are always invited to sing and dance in honour of the person in question. In another vein, the National Sports Festivals which Nigeria organizes every two years is also a good example of occasional festivals that brings young people together to compete for prizes, the annual challenge (now called Federation cup) football cup, the Music Project Fame organized by a telecommunication company and the likes are all occasional festivals. (Lawrence-Hart, 2012:125)

\section{Phenomenological Survey of Selected Festivals} the society.

It is imperative to examine some cultural festivals and how they aid social and cultural integration in

\section{The Osun Osogbo Cultural Festivals}

The Osun Osogbo cultural festivals is a unique annual celebration in honor of the River goddess called Osun in Osun State. The festivals have acquired an International status which is observed by both Nigerian and foreigners. The festivals are in commemoration of the event that led to the founding of Osogbo town and the renewal of the mystic bond between the people of Osogbo. River Osun was believed to have provided the water of life which saved the inhabitants of ancient Osogbo town from hunger, pestilence and religious wars centuries ago. It is believed to provide protective guidance till today and the annual celebration is therefore done in reverence and appreciation to the goddess Osun otherwise referred to as the goddess of fertility (NTDC, 2004:23 ). The Osun is a very powerful deity while the river has mystically divine creatures living under the water. She is the guardian of the divinity of the founders of Osogbo and is believed to have the ability to give children to barren women. Also she has the power to heal the sick and the afflicted by means of medicinal water. The medicinal water is sacrosanct and this is why Osun is worshipped daily and elaborately celebrated every year in August with pomp and ceremony. 
The Arugungu Fishing Festivals

This is another festival that has gained prominence in recent times; this can be attested to by the turnout of participants both from within and outside Nigeria. Historically, the festival started as an irregular get-together of the local fishermen residing within the immediate vicinity of the fishing site of Argungu settlement in the present Kebbi State of Nigeria. The main period of fishing is the dry season stretching from the month of December to May. This is the period of less agricultural activity and also the time when the floods would have subsided, people go into fishing because it is a time when farming is drastically reduced. The method of catching fish is the use of a pair of seine nets known as Homa which are held in each hand of the fishermen. Some other cultural events that make the festivals thick include Kabauchi displays, agricultural fair, traditional dances, drama, boxing, wrestling, camel, donkey and horse races etc. as well as motor rally, bicycle rally and archery as other compliments. The climax of the festivals is when the signal is given for fishing to start and the fishermen charge into the river amidst music and songs. Once the fishing is over, fishermen are forbidden from fishing on the spot again until the next fishing festivals. The person with the biggest catch carries the day (NDTC, 2004:1).

\section{Kwagh-hir Puppet Theatre Festivals}

This festival represents the supernatural belief in Tiv land. It features puppets and masquerades that dramatize the pranks and habits of animals and the magic of the spirits. The love for stories, songs and the skill for handwork especially carvings by the Tiv people are also portrayed. The Kwagh-hir performances usually consist of drummers, singers, acrobats as well as various works of arts. The theme of the Kwagh-hir festivals is woven around economic and social problems of the people, traditional and historic issues in Tiv land. It normally comes up in November or December annually.

\section{Durbar Festivals}

This festival constitute a spectacular parade of horsemen from sections of Kano and Kastina Emirates assembled to exhibit horsemanship and pay homage to the Emir during the Salah festivals and as a mark of honour for visiting dignitaries on special occasions. Now, the Dubar is not restricted to Kano and Kastina Emirates but also a common feature of most Emirates of Northern Nigeria. It is a colourful procession which features contests among the royal cavalry, drummers and trumpeters, praise singers and wrestler (NTDC, 2004:3).

All these festivals mentioned above brought people of various strata from different locations together, both at the local and international level. People made new friends and business contact, the youths were engaged in one activity or the other; while some were involved in doing brisk business as such avenues provided opportunity for different kind of businesses to thrive.

\section{Theoretical Alignment}

Festivals can be best explained using the functionalist theory; this is because functional theory argues that social institution is a collective means to meet individual needs. Functionalist maintains that social institutions are functionally integrated to form a stable system and change in one institution and will precipitate a change in the other institutions as societies are seen to be coherent, bounded and functions like organism with their various parts. The various parts of the society are walking toward the maintenance of social equilibrium. Therefore, all social and cultural phenomena are seen as functional in the sense of working together to achieve a set goal. This functions is the contribution they make to the larger system of which they are part. (Dougherty and Pfalttzgraff 1997:101). Functionalism views the society as integrated whole where each unit or sub-system is interdependent with the other social system. This implies that any unit that has no function ceases to exist. Hence, festivals have functions within the social system as it has continued to thrive.

\section{Festivals and Peace}

One common factor in all these festivals is that it has an atmosphere of merriment, celebration and draws people from all works of life together. Festivals engender peace because it creates euphoria of feasting and meeting people of different strata and religious inclination. This can be seen when Christian clerics come together to break the Ramadam fast with their Muslim brothers even in the heat of the Boko Haram menace, although there was a snag due to the bombing on a Christmas day but the fact that it was condemned by the Muslim community shows their disassociation with the perpetrators of the dastardly act. In the same vein, during the Christmas and Easter celebration, especially in the Western part of Nigeria where they have a mix of adherent of Islam and Christianity, The Muslims join in the celebration with their Christian brothers, this shows elements of peaceful co-existence despite their religious differences. During these periods of celebration, there is always a get-together and unity of purpose though they come in their seasons as slated in their religious calendars. During the Id-el-fitr celebration, President Goodluck Jonathan in the spirit of the celebration called 
on Nigerians to embrace peace and unity in order to achieve meaningful development, the president said '.....first and foremost, for us to progress, we must unite, for us to progress there must be peace and I believe that even the challenges we are passing through, we will overcome them if we are united and embrace peace' (Leadership Newspaper 12-8-2012).

In the case of cultural festivals like Arugungu of Kebbi State, we see people from all works of life irrespective of their social standing, culture and religion coming together in the spirit of celebration. Competition for the biggest catch is open to all while other side attractions like music are there to make the atmosphere lively.

Festivals also play a significant role in the lives of people in a community because they provide important activity outlets for both locals and visitors as leisure pursuits (Getz, 1993:65) for instance the just concluded 2012 Olympics games in London, people travelled from all over the world to witness different sporting activities, it was also observed that apart from sporting activities people had get-together within the London Sports Stadium where different cultural group came to entertain visitors. They had the African Stand, Asian Stand, Caribbean Stand and others; they were served their local cuisine and entertained with their local music. Festivals indeed help build social cohesion by reinforcing ties within a community, other than entertainment. Rao (2001:24) maintains that festivals provide a specific time and place for families to demonstrate their commitment to their community. By participating in festivals, families can interact with other families in a mutually enjoyable environment, allowing them to develop strong relationships with one another. For instance, the Maltina Family Dance Show which brings families together to dance for a prize.

Although one cannot rule out the fact that conflict may arise in cause of festival celebration which may lead to great loses but its gain cannot be compared with the crisis and damages on our society by its neglect, this is because periods of festivals are seasons of merriment and engagement in one activities or the other, for instance, during the Project Fame (a music festivals organized by a Telecommunication Company to hunt for talented singers) young men and women were drawn from divers culture, tribe and tongue, they came together to rehearse and sing. Hence with continual interaction they became acquainted with each other thereby breaking cultural barriers, increasing cultural ties and bond among people from different cultural group and also creating a platform for intercultural communication. The gains of festivals is also very glaring when it involves winning prizes as the innovative sense of both youths and elders are unleashed in mapping out strategies to either attract viewers or win the set prize, so instead of being engaged in social vices and acts of violence they are occupied with thoughts of how to achieve their set targets. Festivals have both positive and negative impacts on their host cities, but emphasis in this paper is focused on its merits rather than the demerits.

\section{Benefits of Festivals}

Festivals as explained above have some characteristic features and benefits which are inherent in its practices both to the individuals and the society at large. For Rao (2001:97) festivals are a recreational activity as it affords people the opportunity to engage in activities that is pleasurable. Most festivals are activities that bring happiness and peace of mind to the participants or spectators. During festive periods like Christmas or Idel-fitr, people make out time for a refreshing break from monotony of work especially in these days that we are too busy to take out time for our near and dear ones. We have no time to introspect, no time to interact. Period of festivals brings people together and make people feel homely. More so, participation in cultural festivals gives a recreation that brings one close to nature.

E.P Modum (1978:56) observed that participation in regular festive activities serves as a means of relaxation of the mind. The physical activities involved in festivals helps in the long run in maintaining sound health and achieving a peace of mind, this probably, might be one of the reasons why our ancestors lived longer in age as they were always involved in regular festive activities which unknown to them enhanced their physical and mental health and improved the quality of life. Festive activities are more of exercise or sport than one can think of; Modum concludes his work on festivals by saying that

In a society that had none of the modern recreational facilities such as television, cinema and tennis, festivals were bound to be an important element of diversion and relaxation as well as a means of social interaction.

Regular participation in festive activities results in the enhancement of interpersonal and intrapersonal skills. Apart from a time of relaxation, festivals are a way of socialization as it creates opportunity of meeting with loved ones and enjoys reunion. Festivals gives people opportunity to meet new people, develop new friendship and strengthen family relationship. In terms of the moral values of society, festivals played regulatory role and constituted the best expression of the African's desire to communicate with his gods and ancestors, to take part in the process of cosmic regeneration and harmony. Festive life perpetuated certain values of the traditional society and even guaranteed its survival. E.P. Modum (1978:56)

Again when people are empowered economically it creates stability and reduces violence, hence, festivals hosting generates economic gain to the host community in that people bring their wares or goods for 
visitors to buy. At this period people also buy new clothes for themselves and their children, food for entertainment, etc. consequently; it becomes a beneficial factor to the people. Benefits of festivals is abundant among them, there is a considerable focus on developmental benefits of festivals for the host community. It should be noted that for some festivals in rural communities, this impact might be limited and relatively small. However, the magnitude of the economic impact of festivals in rural communities depends on the characteristics of the festivals such as the length of the festivals as well as factors in the local economy such as other visitor attraction in the community (Crompton \& McKay, 1994:73).

Festivals provide personal benefits such as new or increasing recreational opportunities for families, individuals and communities. Festivals provide excitement, fun, and great cultural entertainment for people in the community. Festivals also provide an opportunity to involve people in community activities who have not previously been active. "Festivals are often intimately related to maintenance and celebration of community values and, ultimately, to their survival". In fact, in the case of small festivals, a local identity is often the most important outcome (Kim \& Uysal, 2004:35). Festivals have a number of impacts on the host city, ranging from cultural, economic, social and environmental.

\section{Conclusion}

The role of festivals in fostering peace and social cohesion in the society cannot be overemphasized because virtually every festivals is filled with fun, entertainment and reinforces solidarity as well as strengthen ties among members of the community, this is because during festivals people are assigned with different roles in preparation for the celebration. Festivals celebration also creates room for exchange, innovation and creativity as it expresses the tangible and intangible expressions and manifestations of the society's values and beliefs. Also important, is the communal life which festivals portray especially in creating a very high level of socialization among people of different culture. More so, hosting of festivals can create opportunity for economic empowerment as people produce locally made goods for sale as souvenirs thereby boosting local economy which will result to less dependence on government and facilitate development which in turn reduce community agitation which most often leads to violence.

\section{Recommendation}

Having x-rayed the enormous benefits of festivals there should be a concerted effort by the government to promote and institutionalize cultural, secular or religious festivals at a National scale to sustain its gain of peaceful society. Peace is paramount for the development of any society and one instrument which will facilitate peace is festivals, therefore the government should create an enabling environment for local communities and cultural groups in the country to regularly organize festivals irrespective of its nature as to keep its citizens lively and engaging, more so they should encourage competitive festivals among the youths. Effort should be made in encouraging cross cultural festival to break cultural ties among the diverse ethnic groups in Nigeria.

Most often public holidays are declared during period of religious festivals, these holidays should not just be periods of relaxation at home by the different adherents but periods of enlightenment and advocacy for a peaceful co-existence among the multi-religious people of Nigeria.

\section{References:}

[1]. Ejizu C.I. and Ozo-mekuri Ndimele (Eds.) (2007). Kiabara Readings on Religion and Culture in

[2]. Africa. Journal of Humanities. University of Port Harcourt, Nigeria

[3]. Crompton, J. and MacKay, S. L. (1994) 'Measuring the economic impact of festivals and events: some myths, misapplications and ethical dilemmas,' Festival Management and Event Tourism’ 2(1): 33-43.

[4]. Kim.k.and Uysal (2004) Tourism Management, Vol 25 Issue 2

[5]. Lawrence-Hart G. (2012) Religio-Cultural Festivals and Tourism in Rivers State. An

[6]. Unpublished PhD Dissertation. University of Port Harcourt.

[7]. Getz, D. (1993) Festivals, Special Events and Tourism New York:Van Nostrand Reinhold.

[8]. Modum E.P in Kalu Ogbu (Ed.) (1978). African Cultural Development. Fourth Dimension

[9]. Publishing Co. Ltd. University of Nigeria

[10]. Rao.V (2001) Journal of Development studies

[11]. UNEP (2002) [Internet] http://www.uneptie.org/pc/tourism > Accessed on [29/02/2010]

[12]. NTDC (2004) An official Report on Osun Osogbo cultural Festival.

[13]. NTDC (2004) An Official Report on Arungun Fishing Festival.

[14]. NTDC (2004) An Official Report on Durbar Festival.

[15]. The American Heritage Dictionary of the English Language, $4^{\text {th }}$ Edition 2009. Houghton Mifflin Company. 